\title{
COMUNICAÇÃO CIENTÍFICA E REDES SOCIAIS
}

A comunicação científica pode ser definida como um espaço onde a informação científica é compartilhada com outros cientistas. Este sistema foi pensado e construido há 300 anos. É um sistema consolidado e está sendo modificado pelas tecnologías digitais de informação e comunicação, que apresentam novas formas para produção, organização e, principalmente, comunicação de informação científica.

O periódico científico continua sendo o principal canal para a publicização das pesquisas, e também é o espaço comunicacional onde ocorre as principais inovações tecnológicas relacionadas com o compartilhamento das pesquisas entre os cientistas. A inovação proporcionada pelas tecnologias digitais de informação e comunicação ocorre em nível de gerenciamento de fluxo informacional, recursos humanos e, especialmente, na incorporação das redes sociais digitais.

Assim, as redes sociais digitais estão se tornando instrumentos importantes, colaborando com o periódico para a comunicação das informações relativas às pesquisas científicas. Nesse contexto, é importante ressaltar o papel das redes sociais digitais na ampliação de usuários, pois o conhecimento científico não deve ser disseminado apenas entre os pares. É preciso torná-lo visível e despertar interesses na sociedade como um todo.

Nessa perspectiva, a Revista Conhecimento em Ação (RCA) se encontra presente nas redes sociais com vistas à promoção da divulgação científica em rede.

No Facebook da RCA (https://www.facebook.com/RevistaConhecimento$\underline{\text { emAcao/) }}$ estão sendo postadas informações relativas aos editoriais, artigos publicados na revista, diretrizes para os autores realizarem as submissões na RCA, eventos científicos da área de Ciência da Informação e informações que promovam 
a educação dos usuários acerca de conteúdos relacionados à comunicação científica, identificadores digitais, bases de dados e informações relacionadas. Essa divulgação é realizada através de imagens e links de redirecionamento, bem como por meio de chamadas para acesso ao conteúdo publicado no periódico.

No Instagram da RCA (@revistaconhecimentoemacao) estão sendo postados feed de notícias e stories com informações relativas aos editoriais, artigos publicados na revista e informações que promovam a educação dos usuários acerca de conteúdos relacionados à comunicação científica, identificadores digitais, bases de dados e informações relacionadas.

O Blog Conhecimento em Ação (https://conhecimentoemacao.blog.br/), por sua vez, dissemina as informações publicadas em ambas as redes sociais supracitadas através de notícias, imagens e links de redirecionamento.

Nesse contexto, estamos caminhando para incorporar as redes sociais digitais de pesquisa aos sistemas clásicos de comunicação científica, e exercitar a premissa da responsabilidade social da Ciência da Informação, de que todos precisam ter acesso à informação.

Gustavo Henrique de Araujo Freire Editor 